\title{
Human bone morphogenetic protein-2 (hBMP-2) characterization by physical-chemical, immunological and biological assays
}

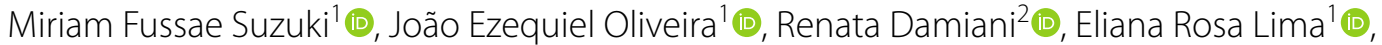 \\ Kleicy Cavalcante Amaral ${ }^{1} \mathbb{0}$, Anderson Maikon de Souza Santos ${ }^{3} \mathbb{C}$, Geraldo Santana Magalhães ${ }^{4} \mathbb{D}$, \\ Leonardo Perez Faverani ${ }^{3} \mathbb{D}$, Luis Antonio Violin Dias Pereira ${ }^{5}$, Fabiana Medeiros Silva ${ }^{2}$ \\ and Paolo Bartolini ${ }^{* *}$
}

\begin{abstract}
Commercially available preparations of methionyl-human BMP-2 and CHO-derived hBMP-2, which belongs to the transforming growth factor $\beta$ (TGF- $\beta$ ) superfamily, were used for a complete characterization. This protein is an extremely efficient osteoinductor that plays an important role during bone regeneration and embryonic development. Characterization was carried out via SDS-PAGE and Western blotting, followed by reversed-phase HPLC, sizeexclusion HPLC and MALDI-TOF-MS. The classical in vitro bioassay, based on the induction of alkaline phosphatase activity in C2C12 cells, confirmed that hBMP-2 biological activity is mostly related to the dimeric form, being $\sim 4$-fold higher for the $\mathrm{CHO}$-derived glycosylated form when compared with the E. coli counterpart. The E. coli-derived methBMP-2 has shown, by MALDI-TOF-MS, a large presence of the bioactive dimer. A more complex molecular mass (MM) distribution was found for the $\mathrm{CHO}$-derived product, whose exact MM has never been reported because of its variable glycosylation. A method based on RP-HPLC was set up, allowing a quantitative and qualitative hBMP-2 determination even directly on ongoing culture media. Considering that hBMP-2 is highly unstable, presenting moreover an extremely high aggregate value, we believe that these data pave the way to a necessary characterization of this important factor when synthesized by DNA recombinant techniques in different types of hosts.
\end{abstract}

Keywords: BMP-2, Escherichia coli-derived, CHO cell-derived, C2C12 bioassay, Efficient osteoinductor

\section{Introduction}

Human bone morphogenetic protein-2 (hBMP-2), one of the most efficient osteoinductors ever described, derives its discovery from the biological basis of bone morphogenesis, set up in the pioneering works of Urist and cols. (Quaas et al. 2018; Strates et al. 1971; Urist 1965; Urist and Strates 1971). Its final purification and characterization from demineralized bone matrix, was carried out

\footnotetext{
*Correspondence: pbartoli@ipen.br

1 Biotechnology Center, Instituto de Pesquisas Energéticas e Nucleares, IPEN-CNEN/SP, Avenida Prof. Lineu Prestes 2242, Cidade Universitária, São Paulo, SP 05508-000, Brazil

Full list of author information is available at the end of the article
}

by the Reddi laboratory (Reddi and Huggins 1972; Sampath et al. 1987; Sampath and Reddi 1981), which opened the way to its cloning and $\mathrm{CHO}$-derived synthesis at the Genetics Institute of Cambridge, MA, USA (Israel et al. 1992; Wozney et al. 1988).

BMP-2 is a homodimeric cysteine-knot protein, belonging to the transforming growth factor- $\beta$ (TGF- $\beta$ ) family, whose structure is stabilized through dimerization and by an additional intermolecular disulfide-bond (Quaas et al. 2018; Scheufler et al. 1999). Due to its unique capacity of inducing bone regeneration and ectopic bone formation in adult vertebrates, its recombinant form is a good alternative to autologous bone grafting, used in many orthopedic applications such as
Springer Open (c) The Author(s) 2020. This article is licensed under a Creative Commons Attribution 4.0 International License, which permits use, sharing, adaptation, distribution and reproduction in any medium or format, as long as you give appropriate credit to the original author(s) and the source, provide a link to the Creative Commons licence, and indicate if changes were made. The images or other third party material in this article are included in the article's Creative Commons licence, unless indicated otherwise in a credit line to the material. If material is not included in the article's Creative Commons licence and your intended use is not permitted by statutory regulation or exceeds the permitted use, you will need to obtain permission directly from the copyright holder. To view a copy of this licence, visit http://creativeco mmons.org/licenses/by/4.0/. 
spinal fusions, oral surgery, bone, cartilage, tendons and ligaments repair, in general (Boden 2000; de Freitas et al. 2016; Kirker-Head 2000; Vallejo et al. 2002; Wikesjo et al. 2009).

One of the most widely used recombinant preparations of hBMP-2 is CHO-derived Infuse ${ }^{\circledR}$ from Medtronic (Even et al. 2012; Ong and Bouazza-Marouf 2000), but a variety of $E$. coli-derived preparations, obtained through in vitro refolding of inclusion bodies, have also shown good biological activity (Bessho et al. 2000; Lee et al. 2011; Long et al. 2006; Quaas et al. 2018; Ruppert et al. 1996; Vallejo et al. 2002). Several in vivo and in vitro studies have also clearly demonstrated their comparable osteoinductivity and clinical efficacy (Harada et al. 2012; Jin et al. 2019; Lee et al. 2013; Yano et al. 2009).

Considering that hBMP-2 has in general an extremely high aggregate value, a careful use of its precious commercial products, also considered a type of reference preparations, is mandatory for studying its characteristics and properties and, eventually, planning alternative and more efficient synthesis processes. Our research group has therefore chosen two specific preparations: the first is an E. coli-derived met-hBMP-2 obtained by proprietary techniques at GenScript (Piscataway, NJ, USA), while the second is the previously mentioned $\mathrm{CHO}$ derived Infuse ${ }^{\circledR}$, from Medtronic (Minneapolis, MN, USA). Therefore, in the present work, the two preparations have been extensively characterized via SDS-PAGE and Western blotting, reversed-phase HPLC (RP-HPLC) and size-exclusion HPLC (HPSEC), MALDI-TOF-MS and the classical in vitro bioassay based on the induction of alkaline phosphatase activity in murine myoblastic C2C12 cells. A novel methodology based on RP-HPLC has also been validated and has shown to be able to quantitatively and qualitatively determine hBMP-2 in E. coli extracts even during the fermentation process.

\section{Materials and methods}

\section{Commercial preparations of recombinant hBMP-2}

Two commercial preparations of recombinant hBMP-2 were used: met-hBMP-2 from E. coli (GenScript, Piscataway, NJ, USA), a dimer of two identical proteins which was lyophilized by the manufacturer after extensive dialysis against $50 \mathrm{mM}$ acetic acid and reconstituted in our laboratory in $20 \mathrm{mM}$ acetic acid, and Infuse ${ }^{\circledR}$, a disulfidelinked dimeric protein molecule with two major subunit species of 114 and 131 amino acids. Each subunit of the latter is glycosylated at one site with high-mannosetype glycans. Infuse ${ }^{\circledR}$ is produced by Medtronic (Minneapolis, MN, USA) in a genetically engineered Chinese hamster ovary $(\mathrm{CHO})$ cell line, lyophilized together with excipients by the manufacturer and reconstituted in our laboratory with sterile water, presenting then a $\mathrm{pH}$ of 4.5 (Medtronic Medical Information Sheet, 2015).

\section{SDS-PAGE and Western blotting}

E. coli-derived met-hBMP-2 (GenScript) and CHOderived hBMP-2 (Infuse ${ }^{\circledR}$ ) were analyzed under reducing and non-reducing conditions (Soares et al. 2000). Coomassie Brilliant Blue G-250 was used for the staining. For Western blotting, the semi-dry transfer technique was utilized on a nitrocellulose membrane, with antihBMP-2 affinity-purified rabbit IgG (1:2000) (Biovision, Milpitas, CA, USA) and goat anti-rabbit IgG conjugated to horseradish peroxidase (1:5000). Protein visualization was performed with Luminata Forte (Merck, Burlington, MA, USA) on X-ray film (CL-Xposure ${ }^{\mathrm{TM}}$ Film, Thermo Scientific, Rockford, IL, USA).

High-performance size-exclusion chromatography (HPSEC) HPSEC for analytical and preparative purposes was carried out on a G2000 SW column $(60 \mathrm{~cm} \times 7.5 \mathrm{~mm}$ I.D., particle size of $10 \mu \mathrm{m}$ and pore size of $125 \AA$ ) from Tosoh Bioscience (Montgomeryville, PA, USA), connected to a Shimadzu Model SCL-10 A HPLC apparatus. Detection was by UV absorbance at $220 \mathrm{~nm}$ with a flow rate of $1.0 \mathrm{~mL} / \mathrm{min}$, employing $0.15 \mathrm{M} \mathrm{NaCl}$ in $0.02 \mathrm{M}$ sodium phosphate buffer, $\mathrm{pH} 7.0$, as the mobile phase.

\section{Analytical reversed-phase high-performance liquid chromatography (RP-HPLC)}

RP-HPLC was carried out with a Jupiter C4 column (25 cm $\times 4.6 \mathrm{~mm}$ I.D., $5 \mu \mathrm{m}$ particle size and $300 \AA$ pore size), connected to a $4 \times 3 \mathrm{~mm}$ guard column cartridge (Phenomenex, Torrance, CA, USA), inserted into a Shimadzu HPLC apparatus. Chromatography was carried out at $30{ }^{\circ} \mathrm{C}$ with UV absorbance detection at a wavelength of $220 \mathrm{~nm}$. Two solutions were utilized: solution A being TFA 1:1000 in $\mathrm{H}_{2} \mathrm{O}$ and solution $\mathrm{B}, 10 \% \mathrm{~A}$ in acetonitrile. For hBMP-2 elution a linear gradient from $30 \%$ $\mathrm{B}(\mathrm{v} / \mathrm{v})$ to $60 \% \mathrm{~B}(\mathrm{v} / \mathrm{v})$ over $30 \mathrm{~min}$ was used, followed by an isocratic elution step with $60 \%$ B for $5 \mathrm{~min}$.

\section{Mass spectrometry for molecular mass determination}

The exact molecular mass determination of rec-hBMP-2, either of $E$. coli or of $\mathrm{CHO}$ origin, and of its different components, was performed via MALDI-TOF-MS at Asparia Glycomics SL (Donostia, San Sebastián, Spain). A diluted protein or glycoprotein solution $(1: 5,1: 10$ and 1:20 from a $1 \mathrm{mg} / \mathrm{mL}$ solution) was mixed $1: 1$ with MALDI matrix solution (sinapinic acid $7 \mathrm{mg} / \mathrm{mL}$ in $0.1 \%$ TFA and $50 \%$ acetonitrile) and spotted directly to the MALDI plate $(1 \mu \mathrm{L})$. The analysis was carried out in linear positive mode, in the range of 5000-40,000 Da in UltrafleXtreme MALDI-TOF-MS equipment (Bruker 
Daltonics, Bremen, Germany). The Open Source Mass Spectrometry tool data processing software was used for increasing resolution analysis.

\section{In vitro hBMP-2 bioassay in $\mathrm{C} 2 \mathrm{C} 12$ cells}

The biological activity of hBMP-2 was determined via induction of alkaline phosphatase activity in murine myoblastic C2C12 cells (Kirsch et al. 2000). Briefly, C2C12 cells (ATCC ${ }^{\circledR}-$ CRL-1772) were grown in DMEM with $2 \mathrm{mM}$ L-glutamine, $0.1 \mathrm{mM}$ non-essential amino acids, $1 \mathrm{mM}$ sodium pyruvate and $10 \%$ fetal bovine serum at $37{ }^{\circ} \mathrm{C}$ and $5 \% \mathrm{CO}_{2}$. One hundred microliters of $\mathrm{C} 2 \mathrm{C} 12$ cells $\left(3 \times 10^{5}\right.$ cells $\left./ \mathrm{mL}\right)$, were added to a 96 well plate, the medium being replaced after $24 \mathrm{~h}$ with fresh medium, $2 \%$ calf serum, and with different concentration of hBMP-2, each point being determined by intra-assay duplicate. After $72 \mathrm{~h}$ cells were lysed in $0.2 \mathrm{~mL}$ buffer A (0.1 M glycerol, pH 9.6, $1 \%$ NP-40, $1 \mathrm{mM} \mathrm{MgCl}_{2}$ and $1 \mathrm{mM} \mathrm{ZnCl}_{2}$ ). Then, $50 \mu \mathrm{L}$ of cell lysates were mixed with $150 \mu \mathrm{L}$ of $0.3 \mathrm{mM}$ p-nitrophenyl-phosphate (Sigma) in buffer $\mathrm{A}$ and incubated at $37^{\circ} \mathrm{C}$ for $30 \mathrm{~min}$. The alkaline phosphatase activity was determined using a Multiskan EX Microplate Reader (Thermo Electron Corporation, Beverly, MA, USA), reading the absorbance at $405 \mathrm{~nm}$.

\section{Results}

A SDS-PAGE analysis of E. coli-derived met-hBMP-2 showed a unique dimeric electrophoretic band $(\sim 24,000 \mathrm{Da})$ which is then totally converted into monomer under reducing conditions (Fig. 1). It is interesting to observe the absolute absence of monomeric form in this GenScript product.

The E. coli-derived preparation was compared, via SDS-PAGE and Western blotting, to $\mathrm{CHO}$-derived hBMP-2 (Infuse ${ }^{\circledR}$ ). One can observe here that Infuse ${ }^{\circledR}$ has a wider and higher MM band under non-reducing conditions, probably due to the presence of differently glycosylated dimeric components that are then reduced to monomeric, glycosylated forms. In the same figure, we can also see the Western blotting of the same preparation with a small presence of highly polymeric forms that were not detected by regular SDS-PAGE.

RP-HPLC analysis detected a type of protein alteration due to a peak with retention time $\left(t_{R}\right)=21.42 \mathrm{~min}$ occurring in met-hBMP-2 and that was found to increase during storage at $-20{ }^{\circ} \mathrm{C}$. Major peaks, with similar retention times (16.77 and $16.34 \mathrm{~min}$ ) and, consequently, with similar hydrophobicity, are observed in both preparations (Fig. 2).

These data are confirmed by HPSEC analysis (Fig. 3), in which Infuse ${ }^{\circledR}$, besides the main peak $\left(t_{R}=20.57 \mathrm{~min}\right)$, presented a small fraction of approximately $10 \%$ $\left(t_{R}=19.66 \mathrm{~min}\right)$, with a higher $\mathrm{MM}$, probably due to a

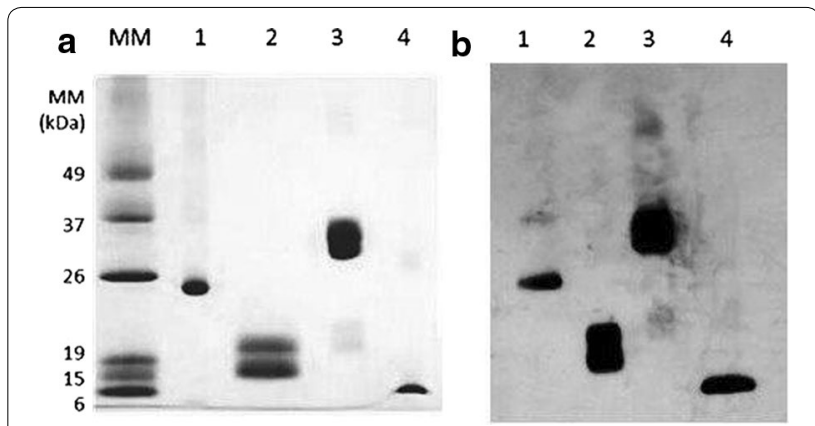

Fig. 1 a SDS-PAGE analysis run in 15\% acrylamide gel, stained with Coomassie Blue G, of: (MM) molecular mass markers; (1) E. coli-derived met-hBMP-2 (GenScript) $1 \mu \mathrm{g}$, run under non-reducing conditions; (2) CHO-derived hBMP-2 (Infuse ${ }^{\circledR}$ from Medtronic) $1 \mu \mathrm{g}$, run under reducing conditions; (3) same sample as in 2, run under non-reducing conditions; (4) same sample as in 1, run under reducing conditions. b Western blot analysis of: (1) E. coli-derived met-hBMP-2, $0.1 \mu \mathrm{g}$, run under non-reducing conditions; (2) CHO-derived hBMP-2 (Infuse ${ }^{\circledR}$ ), $0.25 \mu \mathrm{g}$, run under reducing conditions; (3) same sample as in 2, run under non-reducing conditions; (4) same sample as in 1, run under reducing conditions

glycosylated form, as will be shown below by MALDITOF-MS analysis.

The set up method for qualitative and quantitative RP-HPLC analysis of hBMP-2, even during E. coli fermentation, is presented in Fig. 4, where a conditioned $E$. coli medium (Fig. 4a) is compared to the same medium to which a known amount of the GenScript reference is added (Fig. 4b) and to the pure GenScript preparation (Fig. 4c). One can observe that the added GenScript preparation appears in the same position of previously synthesized hBMP-2. According to this quantitative analysis, the medium shown in Fig. 4a contains $\sim 18 \mu \mathrm{g} / \mathrm{mL}$ of hBMP-2.

MALDI-TOF-MS for exact MM determination of both reference preparations is presented in Fig. 5. We can observe the very high accuracy of the method, considering that the theoretical MM of dimeric met-hBMP-2 is $26,072 \mathrm{Da}$, while the determined mass is $26,054 \mathrm{Da}$, showing a difference of $0.07 \%$ only, either without or with acetic acid addition in its reconstitution, as recommended by the manufacturer. The presence of a small amount of monomeric form can also be observed. In the case of Infuse ${ }^{\circledR}$, not knowing the exact theoretical MM because of possible variable glycosylation, we can see the presence of four major forms, with 14,377 Da; 16,384 Da; 28,732 $\mathrm{Da}$ and 30,798 $\mathrm{Da}$. Knowing that the theoretical protein backbone of authentic monomeric hBMP-2 (i.e. without initial Met and with a total of 114 AA) has a MM of $12,905 \mathrm{Da}$, we can deduce that the $14,377 \mathrm{Da}$ form (that we will call A) can be the 114 AA monomer with $10.2 \%$ carbohydrate moiety, while the $28,732 \mathrm{Da}$ form 

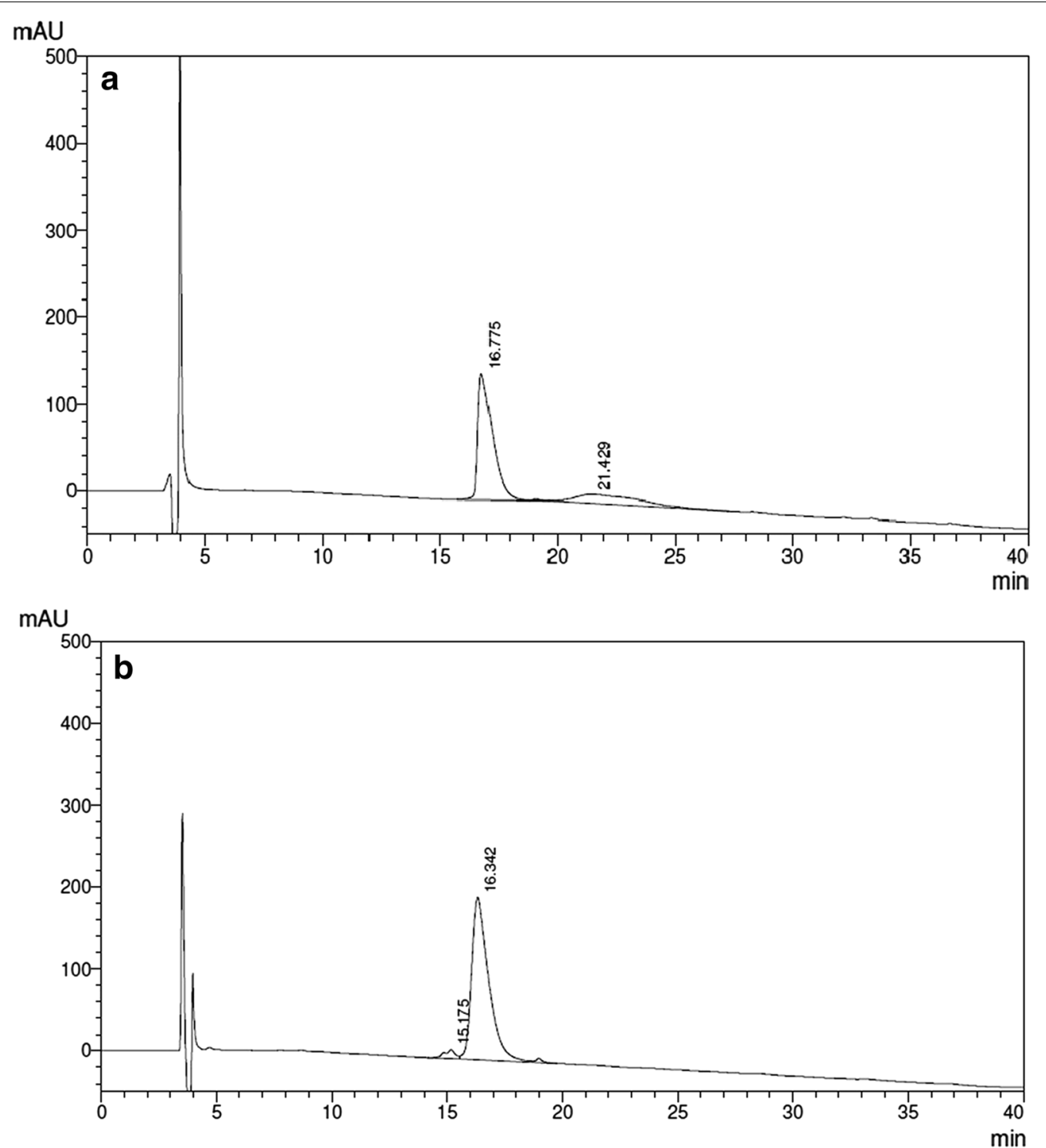

Fig. 2 Reversed-phase high-performance liquid chromatography (RP-HPLC) of: a E. coli-derived met-hBMP-2 (GenScript), $10 \mu \mathrm{g} ; \mathbf{b}$ CHO-derived hBMP-2 (Infuse $\left.{ }^{\circledR}\right), 10 \mu \mathrm{g}$

corresponds to the glycosylated dimer. Following a similar scheme and knowing from manufacturer's data (Medical Information Sheet, Medtronic, Memphis, TN, USA) that Infuse ${ }^{\circledR}$, besides the $114 \mathrm{AA}$, also contains a $131 \mathrm{AA}$ form, we can calculate that this second monomeric peak of $131 \mathrm{AA}$ and $16,384 \mathrm{Da}$ (called $\mathrm{B}$ and having a protein backbone of $\sim 14,800 \mathrm{Da}$ ) would correspond to a similarly glycosylated protein with $\sim 9.6 \%$ carbohydrate. With basis on these assumptions, the 28,732 Da peak would correspond to a dimer of $\mathrm{A}$, while the 30,798 Da peak, almost exactly to $\mathrm{A}+\mathrm{B}$, showing only a $0.12 \%$ difference between calculated and observed mass. Considering what suggested by Israel et al. (Israel et al. 1992), who also confirmed the presence, in mature CHO-derived hBMP2 , of a $\sim 30 \mathrm{kDa}$ homodimer, the monomeric forms of $14.4 \mathrm{kDa}$ and $16.4 \mathrm{kDa}$ are probably variants which only differ by proteolytic processing at their amino termini.

We consider the in vitro bioassay based on the induction of alkaline phosphatase activity in murine myoblastic $\mathrm{C} 2 \mathrm{C} 12$ cells as the "almost final" biological response for hBMP-2 activity. We call it "almost final" because we particularly praise, in this respect, a type of in vivo bioassay carried out in rat calvarial critical-size defects as the one described by Nakamura et al. (Nakamura et al. 2017). The 


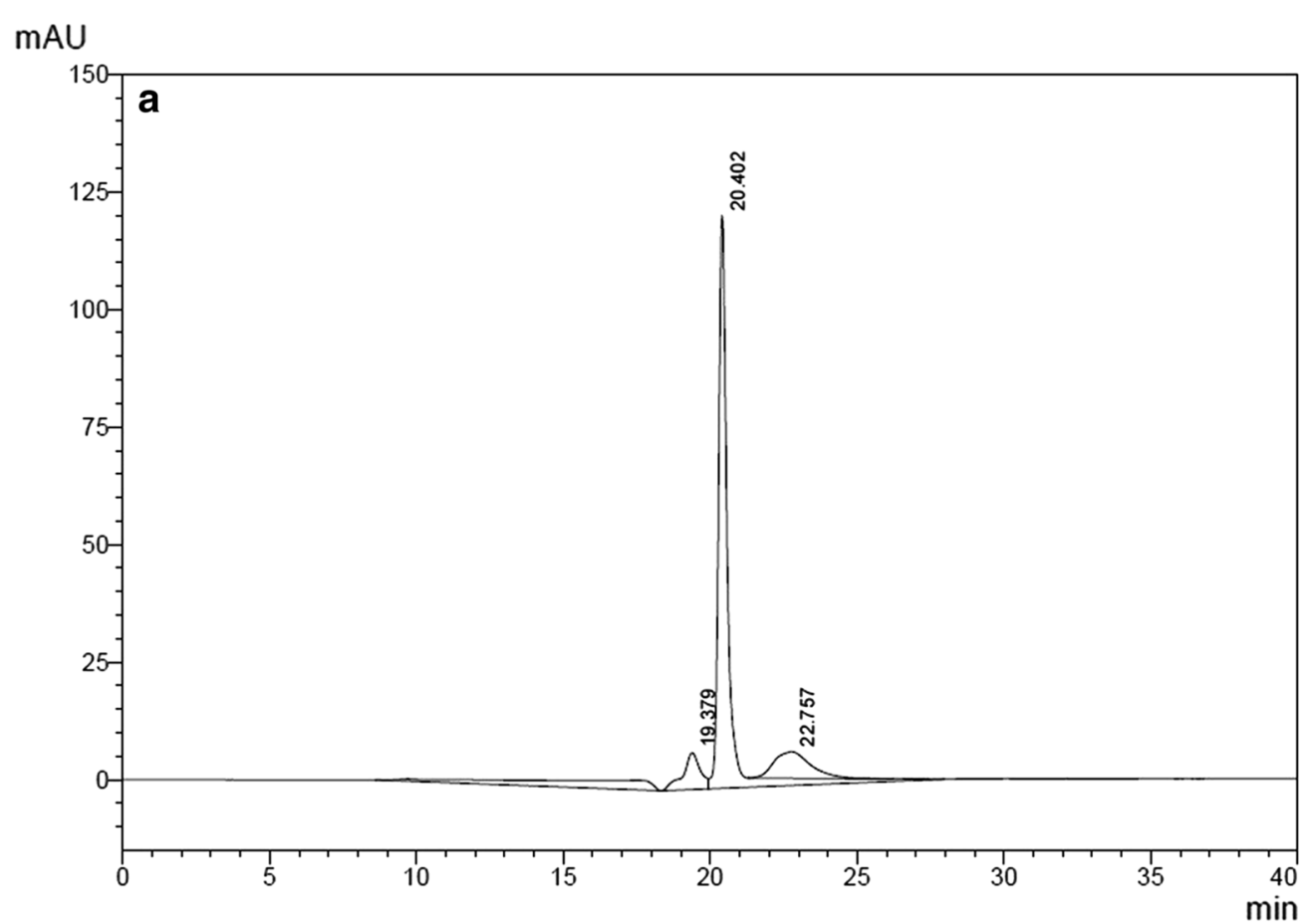

mAU

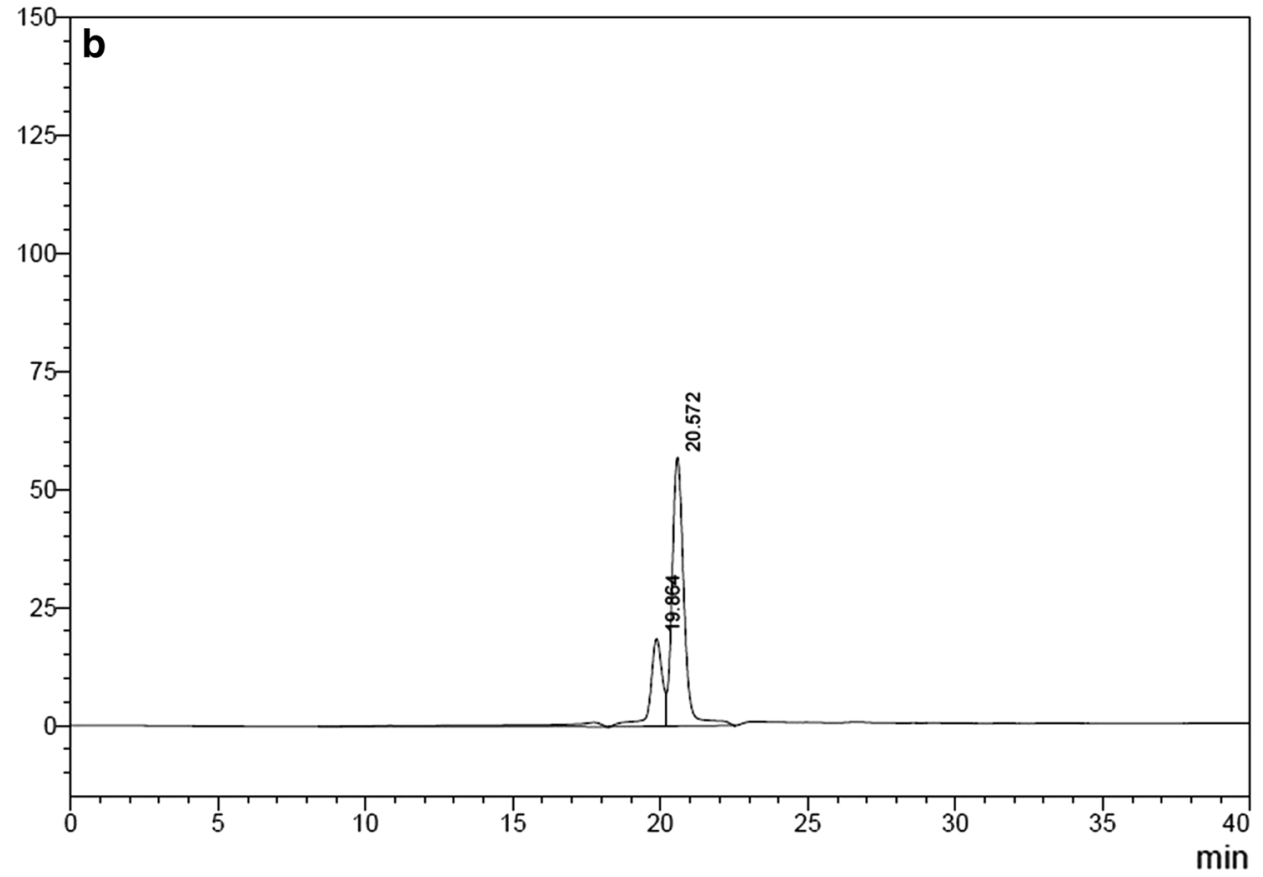

Fig. 3 High-performance size-exclusion chromatography (HPSEC) of: a E. coli-derived hBMP-2 (GenScript), $10 \mu \mathrm{m} ;$ b CHO-derived hBMP-2 (Infuse $\left.{ }^{\circledR}\right)$, $10 \mu \mathrm{g}$

C2C12 in vitro assay, however, is almost final because it is hard to speculate that a good activity in this assay will not provide activity in the in vivo test. On the other hand, the mentioned in vitro assay has been described and utilized by several authors (Kirsch et al. 2000; Long et al. 2006;
Quaas et al. 2018; Vallejo et al. 2002). In Fig. 6, in fact, we are showing the curve carried out in our laboratory with the use of the GenScript preparation. The curve inclination, which is directly related to the potency of the product, was $0.637 \mu \mathrm{g} / \mathrm{mL} / \mathrm{A}_{405}$ in our hands and $0.533 \mu \mathrm{g} /$ 

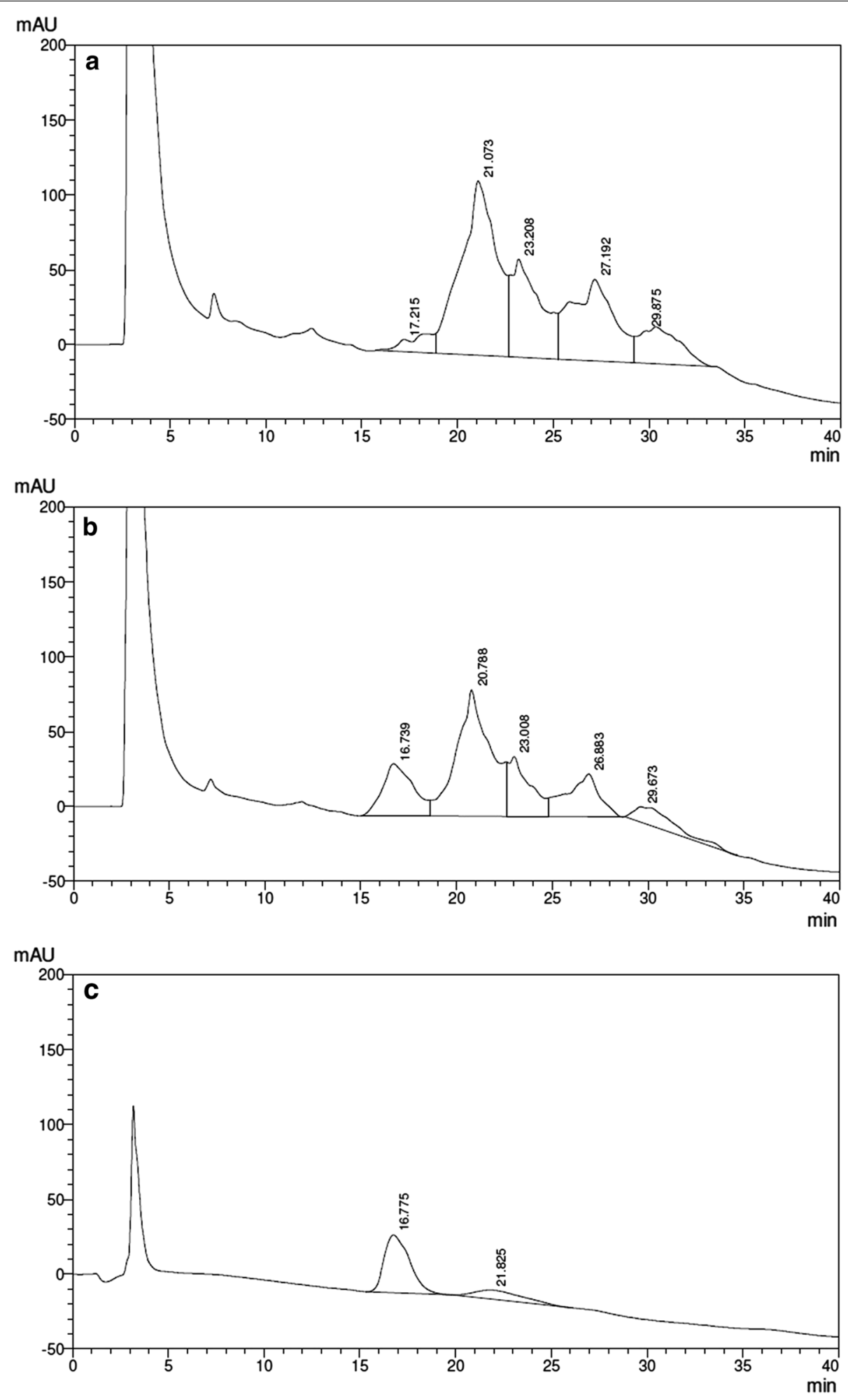

Fig. 4 RP-HPLC quantitative and qualitative analysis of E. coli-derived hBMP-2: a hBMP-2-containing conditioned medium, $100 \mu \mathrm{L} ; \mathbf{b}$ same conditioned medium to which a known amount $(10 \mu \mathrm{g})$ of the GenScript reference preparation was added; c GenScript reference preparation $(10 \mu \mathrm{g})$, used for quantitative determination 

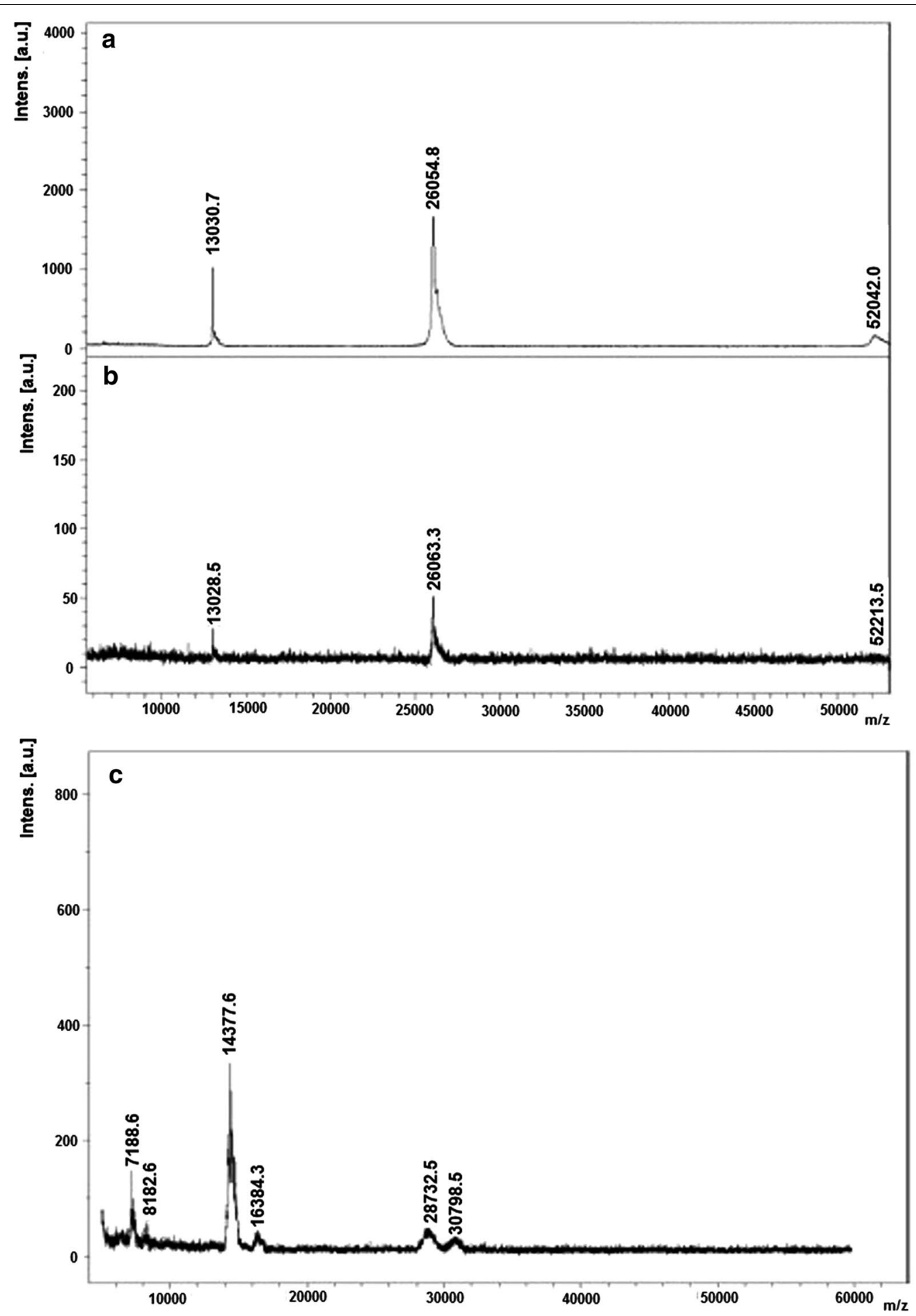

Fig. 5 MALDI-TOF-MS for exact molecular mass (MM) determination of: a E. coli-derived met-hBMP-2 from GenScript (theoretical MM=13,036 Da), lyophilized after extensive dialysis against $50 \mathrm{mM}$ acetic acid; $\mathbf{b}$ same as in "a", reconstituted with $20 \mathrm{mM}$ acetic acid as recommended; $\mathbf{c}$ CHO-derived hBMP-2 (Infuse ${ }^{\circledR}$ ) 


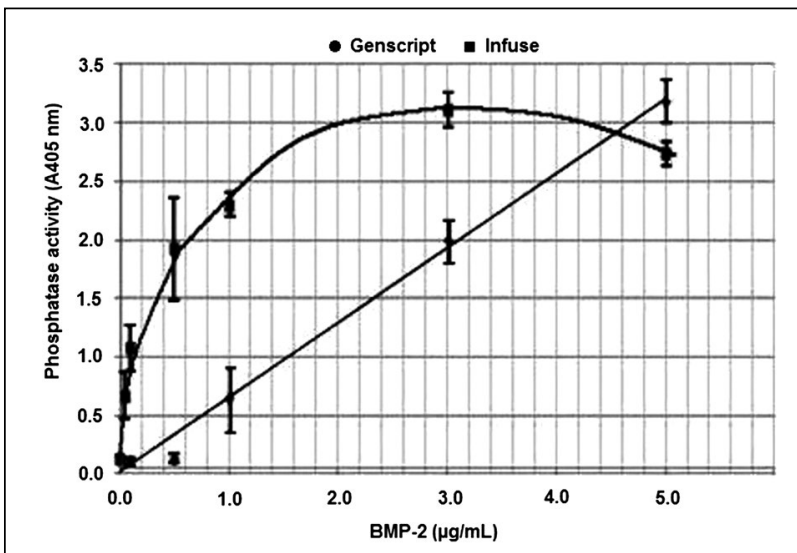

Fig. 6 Biological activity determination of hBMP-2 via induction of alkaline phosphatase activity in murine myoblastic $\mathrm{C2C} 12$ cells, reading at $405 \mathrm{~nm}$ after $72 \mathrm{~h}$ culture. Equations of the assay curves: for E. coli-derived hBMP-2 (GenScript): $Y_{\text {A405 }}=0.637 X_{\mu \mathrm{g} / \mathrm{mL}}-0.011(\mathrm{r}=0.997 ; \mathrm{n}=5 ; \mathrm{P}<0.001)$; $\mathrm{ED}_{50}=2.5 \mu \mathrm{g}$; for $\mathrm{CHO}$-derived hBMP-2 (Infuse $\left.{ }^{\circledR}\right): \mathrm{Y}_{\mathrm{A} 405}=0.682+$ $1.695 X_{\mu \mathrm{g} / \mathrm{mL}}+0.260 X_{\mu \mathrm{g} / \mathrm{mL}}^{2}(r=0.951 ; n=7 ; P<0.001) ; E_{50}=0.4 \mu \mathrm{g}$

mL/A 405 (whole equation: $\mathrm{Y}_{\mathrm{A} 405}=0.533 \mathrm{X}_{\mu \mathrm{g} / \mathrm{mL}}+0.024$; $\mathrm{r}=0.991 ; \mathrm{n}=4 ; \mathrm{P}<0.01)$ in the case of Vallejo et al. analogous curve (Vallejo et al. 2002), providing a similar potency and, in both cases, highly significant statistical parameters. Surprisingly, in our hands, the Infuse ${ }^{\circledR}$ curve did not show a linear correlation but a clear parabolic function, whose equation and $\mathrm{ED}_{50}$ ratio indicate an activity that is $\sim 4$-fold higher than that shown by the GenScript preparation.

In Table 1 , the in vitro bioassays carried out on $\mathrm{CHO}$ derived and on E. coli-derived hBMP-2 all along the present study, have been compared with basis on two widely used parameters for relative potency determination: either the slope of the dose-response curve or the effective dose fifty $\left(E D_{50}\right)$ ratios. The two methods indicated, with an acceptable precision, that the $\mathrm{CHO}$-derived product has indeed a potency 3.4- to 4.6-fold higher than the $E$. coli-derived preparation, in this in vitro bioassay. Unfortunately, a higher inter-assay precision was not easy to obtain, because of the high instability and extremely high cost of these preparations, which does not facilitate the repeated use of recently dissolved products.

\section{Discussion}

Two of the most widely used preparations of hBMP-2, one E. coli-derived and the other $\mathrm{CHO}$-derived, have been compared via physical-chemical, immunological and in vitro biological assays. As already mentioned, these are considered reference preparations and there are some difficulties associated with their use, especially due to their instability.

The E. coli-derived preparation (met-hBMP-2 from GenScript) is declared stable up to 6 months at $-80{ }^{\circ} \mathrm{C}$ in lyophilized form from date of receipt and, upon reconstitution, only up to 2 weeks at $4{ }^{\circ} \mathrm{C}$, or up to 3 months at $-20{ }^{\circ} \mathrm{C}$. The $\mathrm{CHO}$-derived preparation (Infuse ${ }^{\circledR}$ from Medtronic) seems somehow more stable. Its validity, in lyophilized form is declared for approximately 1 year while, upon reconstitution, its immediate use together with the provided collagen sponge is recommended. The constant and repeated use of these working reference preparations is, therefore, quite unpractical. We believe, nonetheless, that our study was quite useful. SDS-PAGE and Western blotting analysis confirmed the prevalent presence of dimeric forms in both preparations. As expected, immunological activity was also present in the monomeric forms and in minor amounts of polymeric forms.

RP-HPLC and HPSEC revealed some alterations in both preparations due to storage, while the latter methodology was not so efficient, at least in our hands, to

Table 1 Comparison between the "in vitro" biological activity of CHO-derived (Infuse) and of E. coli-derived (GenScript) hBMP-2 preparations

\begin{tabular}{|c|c|c|c|c|c|c|}
\hline \multirow[t]{2}{*}{ Assay \# } & \multicolumn{2}{|l|}{ E. coli-derived hBMP-2 } & \multicolumn{2}{|l|}{ CHO-derived hBMP-2 } & \multicolumn{2}{|c|}{$\begin{array}{l}\text { Relative potency of } \mathrm{CHO}- \\
\text { derived hBMP- } 2 \text { with basis on: }\end{array}$} \\
\hline & Slope $^{a}\left(A_{405} / \mu \mathrm{g} / \mathrm{mL}\right)$ & $\mathrm{ED}_{50}(\mu \mathrm{g} / \mathrm{mL})$ & Slope $^{a}\left(A_{405} / \mu \mathrm{g} / \mathrm{mL}\right)$ & $\mathrm{ED}_{50}(\mu \mathrm{g} / \mathrm{mL})$ & Slope (ratio) & $\mathrm{ED}_{50}$ (ratio) \\
\hline 1 & 0.637 & 2.50 & 3.081 & 0.40 & 4.8 & 6.2 \\
\hline 2 & 0.495 & 1.15 & 3.147 & 0.48 & 6.3 & 2.4 \\
\hline 3 & 0.543 & 1.18 & 2.056 & 0.40 & 3.8 & 3.0 \\
\hline 4 & 0.565 & 1.47 & 2.403 & 0.50 & 4.2 & 2.9 \\
\hline 5 & 0.704 & 1.23 & 2.746 & 0.47 & 3.9 & 2.6 \\
\hline Mean \pm SD & $0.589 \pm 0.082$ & $1.51 \pm 0.57$ & $2.687 \pm 0.46$ & $0.45 \pm 0.047$ & $4.60 \pm 1.03$ & $3.42 \pm 1.57$ \\
\hline CV (\%) & 14 & 38 & 17 & 10 & 22 & 46 \\
\hline
\end{tabular}

a Slope of the dose-response curve: $\mathrm{Y}_{\mathrm{A} 405}=\mathrm{a} \mathrm{X}_{\mu \mathrm{g} / \mathrm{mL}}+\mathrm{b}$. In the case of $\mathrm{CHO}$-derived hBMP-2 the equations were calculated with basis on the initial linear region of the dose-response curve 
detect an increased molecular mass of approximately $10 \%$, in the case of CHO-derived glycosylated preparations. RP-HPLC, moreover, was tested and validated as a quite useful approach for quantitative and qualitative analysis of hBMP-2 in its pure form and even directly in culture, confirming the experience of our research group in setting up analogous methodologies (Dalmora et al. 1997; Dias et al. 2018; Oliveira et al. 2003; Soares et al. 2002).

MALDI-TOF-MS molecular mass determination was of great help, providing an accurate method for checking the molecular distribution of the two preparations. Met-hBMP-2 confirmed the accuracy of this methodology while the analysis of Infuse ${ }^{\circledR}$ revealed what molecular forms we are dealing with. The definition, reported in the "Medtronic Medical Information Sheet", that Infuse ${ }^{\circledR}$ is a disulfide-linked dimeric protein molecule with two major subunit species of 114 and 131 amino acids and a single glycosylation site, has been confirmed with more details in Fig. 5 c. This allowed also a calculation that $\sim 10 \%$ of carbohydrate moiety is due to the mentioned single glycosylation site, with probably the presence of complex and high-mannose type $\mathrm{N}$-glycan (Israel et al. 1992). It is known that MALDI-TOF-MS analysis is not strictly quantitative and therefore one can only observe that the Infuse ${ }^{\circledR}$ preparation seems rich in monomeric forms, but this could also be due to artefacts related with the specific analytical technique.

The $\mathrm{C} 2 \mathrm{C} 12$ in vitro bioassay has demonstrated a good accuracy and inter-laboratory reproducibility, through the comparison of two curves obtained with similar $E$. coli-derived hBMP-2 preparation: a published curve (Vallejo et al. 2002) and the present, carried out in our laboratory with the use of the GenScript preparation. A sound comparison, carried out with basis on five different experiments, shown in Table 1, has proved that Infuse ${ }^{\circledR}$ has a much higher in vitro bioactivity than the GenScript preparation, at least at lower doses, while at higher doses $(\sim 5 \mu \mathrm{g} / \mathrm{mL})$ a similar potency is attained. We believe that the Nakamura et al. (Nakamura et al. 2017) approach, used to compare in vivo the osteoinductive potential of two hBMPs (hBMP-2 versus hBMP-9) by treating calvarial critical-size defects in rats, will be very useful for the purpose of studying and defining the in vivo potency of recombinant hBMP-2 preparations of different origins. It will be possible, moreover, to characterize new preparations at the molecular level, with basis on the present data and methodologies.

\section{Acknowledgements}

The authors wish to thank all wonderful teams from the Biotechnology Center (IPEN-CNEN/SP), from Biosintesis P\&D and from UNESP, School of Dentistry (Araçatuba), for all support and collaboration.

\section{Authors' contributions}

PB, LAVDP and LPF designed the study, MFS, JEO, RD, ERL and KCA performed the experiments, GSM, AMSS, MFS and PB analyzed the data, PB wrote the paper, PB and FMS supervised the project. All authors contributed to conceptualizing and implementing the experiments. All authors read and approved the final manuscript.

\section{Funding}

This work was supported by the São Paulo State Research FoundationFAPESP, São Paulo, Brazil (Project no 2015/15446-0 and 2016/24724-6).

\section{Availability of data and materials}

Not applicable.

Ethics approval and consent to participate

This article does not contain any studies with human participants or animals performed by any of the authors.

\section{Consent for publication}

Not applicable.

\section{Competing interests}

The authors declare that they have no competing interests.

\section{Author details}

1 Biotechnology Center, Instituto de Pesquisas Energéticas e Nucleares, IPEN-CNEN/SP, Avenida Prof. Lineu Prestes 2242, Cidade Universitária, São Paulo, SP 05508-000, Brazil. ${ }^{2}$ Biosintesis P\&D, São Paulo, SP, Brazil. ${ }^{3}$ Department of Surgery and Integrated Clinic-Universidade Estadual Paulista Júlio de Mesquita Filho-UNESP, School of Dentistry, Araçatuba, SP, Brazil. ${ }^{4}$ Immunopathology Laboratory, Instituto Butantan, São Paulo, SP, Brazil. ${ }^{5}$ Department of Biochemistry and Tissue Biology, Institute of Biology, Universidade Estadual de Campinas-UNICAMP, Campinas, SP, Brazil.

Received: 7 November 2019 Accepted: 27 January 2020

Published online: 17 February 2020

\section{References}

Bessho K, Konishi Y, Kaihara S, Fujimura K, Okubo Y, lizuka T (2000) Bone induction by Escherichia coli -derived recombinant human bone morphogenetic protein-2 compared with Chinese hamster ovary cell-derived recombinant human bone morphogenetic protein-2. Br J Oral Maxillofac Surg 38(6):645-649. https://doi.org/10.1054/bjom.2000.0533

Boden SD (2000) Biology of lumbar spine fusion and use of bone graft substitutes: present, future, and next generation. Tissue Eng 6(4):383-399. https //doi.org/10.1089/107632700418092

Dalmora S, Oliveira JE, Affonso R, Gimbo E, Ribela MT, Bartolini P (1997) Analysis of recombinant human growth hormone directly in osmotic shock fluids. J Chromatogr A 782(2):199-210. https://doi.org/10.1016/50021 -9673(97)00493-7

de Freitas RM, Susin C, Tamashiro WM, Chaves de Souza JA, Marcantonio C, Wikesjo UM, Pereira LA, Marcantonio E Jr (2016) Histological analysis and gene expression profile following augmentation of the anterior maxilla using rhBMP-2/ACS versus autogenous bone graft. J Clin Periodontol 43(12):1200-1207. https://doi.org/10.1111/jcpe.12601

Dias PVS, Arthuso FS, Oliveira JE, Suzuki MF, Sousa JM, Ribela M, Bartolini P, Soares CRJ (2018) Determination of recombinant Interferon-alpha2 in E. coli periplasmic extracts by reversed-phase high-performance liquid chromatography. J Chromatogr B Anal Technol Biomed Life Sci 1072:193-198. https://doi.org/10.1016/j.jchromb.2017.11.023

Even J, Eskander M, Kang J (2012) Bone morphogenetic protein in spine surgery: current and future uses. J Am Acad Orthop Surg 20(9):547-552. https://doi.org/10.5435/JAAOS-20-09-547

Harada Y, Itoi T, Wakitani S, Irie H, Sakamoto M, Zhao D, Nezu Y, Yogo T, Hara Y, Tagawa M (2012) Effect of Escherichia coli-produced recombinant human bone morphogenetic protein 2 on the regeneration of canine segmental ulnar defects. J Bone Miner Metab 30:388-399 
Israel DI, Nove J, Kerns KM, Moutsatsos IK, Kaufman RJ (1992) Expression and characterization of bone morphogenetic protein-2 in Chinese hamster ovary cells. Growth Factors 7(2):139-150

Jin YZ, Zheng GB, Lee JH (2019) Escherichia coli BMP-2 showed comparable osteoinductivity with Chinese hamster ovary derived BMP-2 with demineralized bone matrix as carrier. Growth Factors 37(1-2):85-94

Kirker-Head CA (2000) Potential applications and delivery strategies for bone morphogenetic proteins. Adv Drug Deliv Rev 43(1):65-92

Kirsch T, Nickel J, Sebald W (2000) BMP-2 antagonists emerge from alterations in the low-affinity binding epitope for receptor BMPR-II. EMBO J 19(13):3314-3324. https://doi.org/10.1093/emboj/19.13.3314

Lee JH, Jang SJ, Koo TY, Suh CW, Lee EN, Lee KM, Lee HS, Baek HR (2011) Expression, purification and osteogenic bioactivity of recombinant human BMP-2 derived by Escherichia coli. Tissue Eng Regener Med $8(1): 8-15$

Lee J, Lee EN, Yoon J, Chung SM, Prasad H, Susin C, Wikesjö UME (2013) Comparative study of chinese hamster ovary cell versus Escherichia coliderived bone morphogenetic protein-2 using the critical-size supralveolar peri-implant defect model. J Periodont 84(3):415-422

Long S, Truong L, Bennett K, Phillips A, Wong-Staal F, Ma H (2006) Expression, purification, and renaturation of bone morphogenetic protein-2 from Escherichia coli. Protein Expr Purif 46(2):374-378. https://doi.org/10.1016/j. pep.2005.09.025

Nakamura T, Shirakata Y, Shinohara Y, Miron RJ, Hasegawa-Nakamura K, Fujioka-Kobayashi M, Noguchi K (2017) Comparison of the effects of recombinant human bone morphogenetic protein-2 and -9 on bone formation in rat calvarial critical-size defects. Clin Oral Investig 21(9):26712679. https://doi.org/10.1007/s00784-017-2069-3

Oliveira JE, de Mendonca F, Peroni CN, Bartolini P, Ribela MT (2003) Determination of Chinese hamster ovary cell-derived recombinant thyrotropin by reversed-phase liquid chromatography. J Chromatogr B Analyt Technol Biomed Life Sci 787(2):345-355. https://doi.org/10.1016/s1570 -0232(02)00965-0

Ong FR, Bouazza-Marouf K (2000) Evaluation of bone strength: correlation between measurements of bone mineral density and drilling force. Proc Inst Mech Eng Part H 214(4):385-399. https://doi.org/10.1243/09544 11001535426

Quaas B, Burmeister L, Li ZP, Nimtz M, Hoffmann A, Rinas U (2018) Properties of dimeric, disulfide-linked rhBMP-2 recovered from $E$. coli derived inclusion bodies by mild extraction or chaotropic solubilization and subsequent refolding. Process Biochem 67:80-87. https://doi.org/10.1016/j.procb io.2018.02.001

Reddi AH, Huggins CB (1972) Citrate and alkaline phosphatase during transformation of fibroblasts by the matrix and minerals of bone. Proc Soc Exp Biol Med 140(3):807-810. https://doi.org/10.3181/00379727-140-36557

Ruppert R, Hoffmann E, Sebald W (1996) Human bone morphogenetic protein 2 contains a heparin-binding site which modifies its biological activity. Eur J Biochem 237(1):295-302. https://doi.org/10.1111/j.14321033.1996.0295n.x

Sampath TK, Reddi AH (1981) Dissociative extraction and reconstitution of extracellular matrix components involved in local bone differentiation. Proc Natl Acad Sci USA 78(12):7599-7603. https://doi.org/10.1073/ pnas.78.12.7599
Sampath TK, Muthukumaran N, Reddi AH (1987) Isolation of osteogenin, an extracellular matrix-associated, bone-inductive protein, by heparin affinity chromatography. Proc Natl Acad Sci USA 84(20):7109-7113. https:// doi.org/10.1073/pnas.84.20.7109

Scheufler C, Sebald W, Hulsmeyer M (1999) Crystal structure of human bone morphogenetic protein-2 at 2.7 A resolution. J Mol Biol 287(1):103-115. https://doi.org/10.1006/jmbi.1999.2590

Soares CR, Morganti L, Miloux B, Lupker JH, Ferrara P, Bartolini P (2000) High-level synthesis of human prolactin in Chinese-Hamster ovary cells. Biotechnol Appl Biochem 32(Pt 2):127-135

Soares CR, Camargo IM, Morganti L, Gimbo E, Oliveira JE, Legoux R, Ferrara P, Bartolini P (2002) Reversed-phase high-performance liquid chromatography method for the determination of prolactin in bacterial extracts and in its purified form. J Chromatogr A 955(2):229-236. https://doi. org/10.1016/0021-9673(02)00229-7

Strates BS, Kirkpatrick SJ, Heffner JE, Urist MR (1971) Effect of chemical modification of tyrosine residues on bone morphogenesis. Biochem J 125(1):367-369. https://doi.org/10.1042/bj1250367

Urist MR (1965) Bone: formation by autoinduction. Science 150(3698):893-899. https://doi.org/10.1126/science.150.3698.893

Urist MR, Strates BS (1971) Bone morphogenetic protein. J Dent Res 50(6):1392-1406. https://doi.org/10.1177/00220345710500060601

Vallejo LF, Brokelmann M, Marten S, Trappe S, Cabrera-Crespo J, Hoffmann A, Gross G, Weich HA, Rinas U (2002) Renaturation and purification of bone morphogenetic protein-2 produced as inclusion bodies in high-cell-density cultures of recombinant Escherichia coli. J Biotechnol 94(2):185-194

Wikesjo UM, Qahash M, Huang YH, Xiropaidis A, Polimeni G, Susin C (2009) Bone morphogenetic proteins for periodontal and alveolar indications; biological observations - clinical implications. Orthod Craniofac Res 12(3):263-270. https://doi.org/10.1111/j.1601-6343.2009.01461.x

Wozney JM, Rosen V, Celeste AJ, Mitsock LM, Whitters MJ, Kriz RW, Hewick RM, Wang EA (1988) Novel regulators of bone formation: molecular clones and activities. Science 242(4885):1528-1534. https://doi.org/10.1126/ science. 3201241

Yano K, Hoshino M, Ohta Y, Manaka T, Naka Y, Imai Y, Sebald W, Takaoka K (2009) Osteoinductive capacity and heat stability of recombinant human bone morphogenetic protein-2 produced by Escherichia coli and dimerized by biochemical processing. J Bone Miner Metab 27:355-363

\section{Publisher's Note}

Springer Nature remains neutral with regard to jurisdictional claims in published maps and institutional affiliations.

\section{Submit your manuscript to a SpringerOpen ${ }^{\circ}$ journal and benefit from:}

- Convenient online submission

- Rigorous peer review

- Open access: articles freely available online

- High visibility within the field

- Retaining the copyright to your article

Submit your next manuscript at springeropen.com 